\title{
The Hidden Self in Self-portrait
}

\author{
Liping Mao,*
}

\author{
${ }^{1}$ Luoyang Normal University, Luoyang, Henan, China \\ *Corresponding author. Email: 102450494@qq.com
}

\begin{abstract}
Self-portrait is a special portrait subject matter. In the process of painting, in addition to depicting his own image, the painter also needs to explore and shape his spiritual self. From the perspective of mental activity, self-portrait is the embodiment of the artist's self-recognition, and this kind of recognition will change in form as conditions change. By observing the self-recognition of the painter in the self-portrait, it will be found that the self-portrait is the artist's record of self-observation, the evaluation of the self under the control of fate, and at the same time a channel to realize the self-recognition and mental perfection as a combination of entity and spirit.
\end{abstract}

Keywords: Self-portrait, Self-recognition, Self-form, Psychology.

\section{INTRODUCTION}

Self-portrait is a special form of portrait painting, and a narrow definition of it is a work in which a painter portrays himself. However, this doesn't mean that the self-portrait is merely a reproduction of the painter's physical appearance. Like a portrait of someone else, a self-portrait is also an expression of the artist's characterization and spiritual outlook of the characters in the painting, and at the same time embodies the painter's aesthetic ideals. In addition, the selfportrait creation process contains a kind of internal observation of the painter's introspective nature, with the content of mental activities of self-analysis and self-judgment. Moreover, many self-portraits are not limited to facial descriptions, and actually include role-playing experiences in their creation process, which are also very meaningful psychological activities. If you conduct an in-depth observation of these activities, you will find a secret window into the origin of the painter's creation, so that you can have a deeper understanding of the deep meaning behind the self-portrait.

\section{A SELF DRAFTED BY A SELF- PORTRAIT}

The first self-portrait recorded in art history was created in 1500 by the German painter Durer during the Renaissance. Humanism was the origin of the great Renaissance Movement that began in the 14th century. With the awakening of people's selfawareness, art began to become an important carrier for expressing human emotions, paying attention to personal dignity, and praising mundane life and the importance of artists began to be recognized by society. In the great work "The Divine Comedy" by the Italian poet Dante, the painters Cimabue and Giotto at that time could be compared with the ancient poet Vergil, which reflected that the society praised highly art and artists then. By the beginning of the 16th century, the Renaissance had reached its peak. At this time, the superior position of artists in the social structure had been established, and the self-portraits of the artists were also produced at that time.

In Durer's self-portrait, he seems to want to portray himself as the image of Christ: The composition of the picture and the posture of the characters are in accordance with the standards of icon paintings, the correct and solemn symmetrical composition is adopted, and the characters are shown frontally. The characters' expression is determined, their eyes are full of wisdom, and the image seems to be supreme, sacred and inviolable. This feeling of sublime can be regarded as Durer's "self-emphasis". For Durer, moulding himself into the image of Christ seems to indicate that God has endowed himself with artistic talents, thus giving him the status of a great "creator" in the field of art.

Like Durer, the elevation of himself to the height of "deity" actually satisfies the painter's 
imagination of perfect self. There are similar examples, for example, Raphael once painted himself in his masterpiece "The School of Athens". Although he pretended to be humble and painted himself in an inconspicuous corner, his image is much more beautiful if you compare it with the image of him painted by others of his time. In fact, the artist's self-portraits didn't have the nature of independent ornamental value at the time or couldn't be sold. Most of the artists' self-portraits were made for research and practice. At the same time, there was another important purpose, which was to show the artist's creative ability. The painter must reflect his outstanding ability in painting in his self-portrait, and at the same time provide the possibility for the painter to shape the personality of the painted object. In a period like the Renaissance, funders who were able to hire painters to make portraits would hope that the appearance of themselves in the works of art is a sublimation of their real self. And the painter's tendency to perfect self-portrait not only satisfies the funders' test of the painter's ability, but also makes them full of curiosity and expectation about what the painter would portray them as. The fundamental reason is that most people regard portraits as a form of their "perfect" personality. In the painter's self-portrait, since the painter's object of observation is himself, his imagination and shaping of himself will not be too restricted. People will easily find that the expression of the so-called portrait is to a large extent the perfect "shaping" of the self in personality.

\section{SELF-RECOGNITION EMBODIED IN SELF-PORTRAITS}

When painting a self-portrait, the painter needs to face the mirror and the canvas to create. This is a process of constant conversion between two different states. When the painter faces the mirror, he strictly observes his own image, however, the image in the painting entrusts his emotions, desires and ideals. The interlacing between the "self" in the mirror and the canvas gives the artist time and space to constantly examine his inner world. In such time and space, the artist actually experiences the profound practice of self-recognition.

Self-recognition is a psychological concept that refers to the insight and understanding of oneself, including self-observation and self-evaluation. In most cases, the self-portrait is the shadow of himself reflected by the life captured by the painter. This shadow is not necessarily the painter's true appearance, but to a large extent expresses the painter's understanding and evaluation of himself. In this sense, self-portrait is the artist's selfrecognition. And self-recognition will directly affect the image of the painter. If some painters' self-evaluation is positive, then the image reflected on the painting should be confident or even proud. On the contrary, if the painter's self-evaluation is negative, then the self-portrait image may be angry and painful.

In Vincent van Gogh's short life, he made more than a dozen self-portraits. In most of these works, the image of Vincent van Gogh presents a state of fanaticism and obsession, which can easily correspond to Vincent van Gogh that people have learned from various records. But one of the most startling self-portraits is "Self-portrait with Bandaged Ears". After experiencing a fatal mental breakdown and a terrifying act of cutting off his ears, Vincent van Gogh painted his image with strong colors. People can't confirm whether Vincent van Gogh really suffers from "mental illness" from this work, and it is also difficult to judge his mental state when he was painting. But people can see a pale and skinny face in front of the red background, with deep-set eyes revealing a look of horror and suspicion. In this painting, people see Vincent van Gogh's face completely different from other selfportraits when facing the despair of life.

The Mexican female painter Frida Kahlo suffered long-term physical damage. More than half of her lifetime's paintings are self-portraits entangled with pain and desire. "Two Fridas" was created shortly after Frida and her husband Rivera divorced. After the divorce, Frida tried to learn to be independent, but failed to end the relationship with her ex-husband throughout her life. Frida's paintings are always straightforward and full of metaphors. Two Fridas holding hands appear in this painting, representing the divided self. Frida on the right is wearing a Mexican native costume with a bare but intact heart, holding a miniature portrait of her ex-husband Rivera in her left hand. Frida on the left is wearing a white Victorian long dress, her exposed heart is cut in half, and her right hand clamps the severed blood vessel with a hemostatic forceps. The two Fridas respectively represent herself from Mexico with indigenous ancestry and herself accepted by Western society with European ancestry. The indigenous Frida is intact on the surface, and the Western Frida is broken, but she stops the bleeding from the broken blood vessel with her own hands. The hearts of two Fridas are connected by a blood vessel, and their hands also 
hold together. This posture of connecting hearts and hands expresses the duality of "Frida" in the simplest and most straightforward way - together they constitute a woman with complex descent and cultural symbols: A woman who was innocent and naive but suffered a tragic experience that others could not imagine, and a woman who loved her husband but decisively decided to end this painful marriage. And this obscure expression of selfrecognition is precisely an appropriate interpretation of complex human nature.

\section{SELF-FORM IN SELF-PORTRAITS}

The Dutch drawing master Rembrandt Harmenszoon van Rijn left more than 90 selfportraits in his artistic career. These works run through the main stages of his life and provided a rich and precious observation sample for studying the self-expression of self-portraits. Comparing the self-portraits of different periods together, one will find that as the painter's age and circumstances change, the self-form expressed in the self-portrait will change accordingly, reflecting the change of the painter's self-consciousness.

In the "Self-portrait" created in 1629, the 23year-old Rembrandt outlined the image of a young soldier in armor, with a young face brimming with confidence and heroism. At this time, Rembrandt was a young artist who just got afoot. This expression of heroism was exactly what he expected for his future at this time - he wanted to be a conqueror on his future artistic path.

In 1635-1636, Rembrandt created "The Painter and His Wife Saskia". At this time, he just achieved success in his artistic career and became a soughtafter object in the market. And his marriage with a rich woman also brought happiness to family life. The 30-year-old Rembrandt held his wife in his arms who was sitting on his lap, raised his wine glass, and smiled on his bearded face. The characters and objects in the painting present a spiraling composition line. The rich dynamics and gorgeous colors give this painting an obvious Baroque style. There are many details in this painting. The sumptuous costumes, exquisite food, and extravagant furnishings all seem to reveal the painter's attitude of showing off. The saber on the painter's waist seems to be a high-profile announcement of the success of the "conqueror".

In another self-portrait painted in 1640, Rembrandt disguised himself as a court minister in the Renaissance period, dressed in costumes with high-quality materials but subtle colors, putting on an elegant posture, and the face is with a kind of noble, composed and elegant grace. Rembrandt was 34 years old when he completed this work. He had established an upper-class position in the field of art and social life. His self-worth judgment had also become stable, and his mentality had become more mature, and he no longer needed to use vanity to prove his success. The composition in this painting is a complete and stable triangle, which shows that the painter's aesthetic orientation has begun to turn to classicism. On the one hand, this style reflects a more elegant taste, on the other hand, it also corresponds to Rembrandt's satisfaction with the status quo, showing his inner determination after he attained social status.

In 1642, the 36-year-old Rembrandt was involved in a lawsuit that tarnished his reputation because of a huge controversy caused by the most important work of his life, "The Night Watch". In June of the same year, his wife Saskia passed away, and his life took a sudden turn and became worse rapidly, facing bankruptcy in just 10 years. In a self-portrait painted during 1643-1648, people can see a face of Rembrandt full of melancholy. At this time, he was about 40 years old and had entered middle age. Although he was still loudly dressed, the costumes were slightly dated. But the main change is that, it can be seen that his heart had lost the calmness he used to have. Faced with the pressure of life, his eyes were full of worry.

In the "A Large Self-portrait" in 1652, the 46year-old Rembrandt was dressed in shabby clothes, but his posture with resting the arms on the hips was still aggressive. His eyebrows were scowling, and his look was cold, showing unruly expression in his eyes. Although he was on the verge of bankruptcy at this time, he still had his new partner Hendrick and his son in his life, and his career seemed to begin to take a turn. Sufferings and setbacks made him melancholy and suspicious. In the painting, he also seemed to tell people such loneliness, but Rembrandt still had the confidence to rebuild his life. In 1654, Hendrick gave birth to a daughter of her and Rembrandt. In the self-portrait of that year, one can see that Rembrandt, who was 48 years old, was beginning to age and looked a little sad, but there seemed to be a lot of tolerance and compassion. It seemed that he had tasted some relief from the birth of a new life, and perhaps more reconciliation with life.

However, late in Rembrandt's life, his doom didn't end. In 1658, Rembrandt's luxury mansion 
was auctioned off to pay off debts. He took his family to move into the gutter, beginning the most difficult and final 10 years of his life. During these 10 years, he basically couldn't receive any orders and lost his second partner and son. But it was during this period with the most hardship that Rembrandt's self-portraits became the treasure of art history. His self-portraits in his later years were introspections of himself, showing complex and changeable psychological levels. In a self-portrait in 1659 when he was 53 years old, he huddled up and his hands clasped together, showing a state of tension. In the painting, he raised his eyebrows and looked at the viewer with a skeptical look. In fact, when painting, the artist should use this kind of vision to look at himself in the mirror. One can interpret Rembrandt's doubts about self-worth from it. While in the "A Self-portrait at the Easel" created in 1660, people can see the image of an old man with a sickly look. The old man's expression was sad, and his tired face revealed poverty and shabbiness. Maybe at this time, he had positioned himself as a loser who struggled with fate, but the paintbrush in his hand showed that he had not put down the weapons in his hand, and had not surrendered to fate.

In "Self-Portrait with Two Circles" created during 1659-1660, people can see Rembrandt with a paintbrush in his hand. His dignity was restored, with a solemn bearing in his body - he was not overwhelmed by his ill-fated and impoverished life. There are two clear arcs on the background of the painting, and these two arcs have a certain connection with the holy light circle in the icon painting. This kind of symbol is the painter's affirmation of self-worth. Its sanctity is not piled up by secular success, nor is it brought by religion, but from Rembrandt's recognition of the noble identity of the artist. In order to maintain this identity, he will not compromise. From this work, Rembrandt's judgment of self can be told — he is a martyr who insists on faith in the field of art, and he will become a noble person admired by future generations because of his persistence.

In 1661, 55-year-old Rembrandt created "As a Self-portrait of Zeuxis' Laughing". Zeuxis was a painter in ancient Greece. He was entrusted by an old woman to paint a portrait of Aphrodite, and the old woman who asked him to paint insisted on being the model in the painting. In the process of painting, Zeuxis thought it was too funny and he laughed wildly, and eventually fell to the ground and died. Rembrandt used rough brushstroke to portray himself as Zeuxis: His face showed an expression that was both crying and laughing. This expression seemed to be a self-mockery, but also hid the meaning of tragedy. However, this is not just a sigh for the fate of individuals, but an experience and reflection on the suffering of human nature. The theme of this work has a deeper meaning. Perhaps Rembrandt smiled bitterly because his works were not understood by the world and he suffered from an absurd fate, or he hoped to die with a smile while painting like Zeuxis, just like a soldier who died on the battlefield.

\section{CONCLUSION}

Through the observation of self-portrait, which belongs to a portrait subject matter, the content of the artist's psychological activities can be more clarified. The painter's self-portrait is not only a formal depiction of the painter's face, but in fact it can't be separated from the painter's psychological activities. Because art faces the spirit directly, selfportrait can also be regarded as a psychological portrait of the painter himself. The presentation of self-portrait includes the painter's observation of self, self-evaluation and expression of ideal personality and it is not changeless and will develop and change with unpredictable factors. Self-portrait, an artistic expression full of unique charm, is the artist's record of self-observation, the evaluation of the self under the control of fate, and at the same time a channel to realize the selfrecognition and mental perfection as a combination of entity and spirit, and these attributes are hidden behind the art of self-portrait. Understanding thoroughly will enable people to capture the deep meaning of portrait paintings.

\section{AUTHORS' CONTRIBUTIONS}

This paper is independently completed by Liping Mao.

\section{REFERENCES}

[1] Lin Dazi. Western Substitutional Self-portrait [J]. LITERATURE \& ART STUDIES, 2011. (in Chinese)

[2] Xu Qing. The Psychological Presentation of Self-portrait in Art [J]. Art Education Research, 2013. (in Chinese)

[3] Ni Jingru. The Life Course of Image Transmission - Taking Rembrandt's Selfportrait as an Example [J]. Writer Magazine, 2014. (in Chinese) 
[4] Pan Xiang. "Real Expression" and "Spiritual Monologue": An Analysis of Rembrandt's Self-portrait Art [J]. Beauty Times, 2017. (in Chinese)

[5] Geng Youzhuang. Body · Art · Revolution Paintings of Frida Kahlo [J]. Art Observation, 2004. (in Chinese)

[6] Zhang Xiaoye. Rembrandt [M]. Shanghai: Jilin Fine Arts Publishing House, 2010. (in Chinese)

[7] [Netherlands] Joannis van Longen. The Story of Rembrandt [M]. Zhou Guozhen trans. Shanghai: Shanghai People's Fine Arts Publishing House, 1997. (in Chinese)

[8] [US] Irving Stone. Lust for Life: The Biography of Vincent van Gogh [M]. Chang Tao trans. Shanghai: Beijing October Literature and Art Publishing House, 2008. (in Chinese) 